\title{
PENGARUH PENAMBAHAN BERBAGAI DOSIS ZAT PENGATUR TUMBUH NAA (NAPHTALENE ACETIC ACID) \\ PADA PUPUK DAUN TERHADAP SIFAT KIMIA TANAH, PERTUMBUHAN, DAN PRODUKSI TANAMAN CABAI BESAR (Capsicum annum L.)
}

\section{The Effect of Addition Various Doses of Plant Growth Regulator NAA (Naphtalene Acetic Acid) on Foliar Fertilization on Soil Properties, Growth, and Production of Great Chilli (Capsicum annum L.)}

\author{
Futihatu Rizkiani Azizah, Syahrul Kurniawan* \\ Jurusan Tanah, Fakultas Pertanian, Universitas Brawijaya, Malang \\ "penulis korespondensi: kurniawan_syahrul@yahoo.com
}

\begin{abstract}
The increase of great chilli concumption may increase great chilli cultivation area in degraded land. To reach high crop production, foliar fertilizer enriched by hormone can be used to improve soil fertility, plant growth and production in great chilli cultivation. This study aimed to determine the effect of addition NAA on soil properties, growth, leaf nutrient content and yield on great chilli. This research took place in Agro Techo Park, Jatikerto Village, Kromengan District, Malang Regency. The study was designed by using a factorial randomized block design with 2 factors that consisted of NAA doses (P1: 0; P2: 75\% NAA; P3: 100\% NAA; and P4: 125\% NAA) and interval application (I1: 14 days and I2: 18 days); each combination treatment was repeated three times. The result showed that difference doses of NAA on foliar fertilizer gave impact on plant growth (i.e height, number of leaf, number of flower per plant, number of fruit per plant) and crop yield of great chilli. Various doses NAA on foliar fertilizer had affected to soil chemical properties (i.e $\mathrm{pH}$, Organic-C, total N, Available P, exchangeable-K and nutrient content (i.e N, P, K) in the leaf of great chilli.
\end{abstract}

Keywords : foliar fertilizer, NAA, great chilli, soil chemical properties

\section{Pendahuluan}

Cabai besar menjadi salah satu komoditas bernilai ekonomi tinggi karena peranannya dalam pemenuhan kebutuhan pangan domestik maupun sebagai komoditi ekspor. Kebutuhan cabai, termasuk cabai besar terus mengalami peningkatan setiap tahun seiring terjadinya peningkatan pertumbuhan penduduk. Banyaknya permintaan cabai dapat dilihat dari konsumsi cabai merah besar pada tahun 2014 yang mengalami peningkatan sebesar 1,46 $\mathrm{kg} / \mathrm{kapita} / \mathrm{tahun}$ dibandingkan dengan tahun 2013 sebanyak 1,42 kg/kapita/tahun (Pusat
Data dan Sistem Informasi Pertanian, 2016). Peningkatan permintaan terhadap cabai besar didukung juga dengan minat petani yang tinggi untuk menanam cabai. Namun, peningkatan produksi dan luas panen cabai tidak selalu terjadi setiap tahun. Di Indonesia khususnya, pada bulan-bulan tertentu kebutuhan cabai tingkat nasional dapat mengalami peningkatan melebihi produksi cabai secara nasional, sehingga tidak dapat memenuhi kebutuhan nasional. Hal ini kemudian berdampak pada kenaikan harga cabai merah besar, terutama di tingkat konsumen. Peningkatan konsumsi cabai yang melebihi batas produksi cabai nasional 


\section{Jurnal Tanah dan Sumberdaya Lahan Vol 6 No 2 : 1301-1311, 2019 \\ e-ISSN:2549-9793, doi: 10.21776/ub.jts1.2019.006.2.11}

menyebabkan harga cabai merah besar cenderung mengalami fluktuasi setiap tahunnya (Pusat Data dan Sistem Informasi Pertanian, 2016).

Selain faktor peningkatan konsumsi, keberhasilan produksi cabai juga bergantung pada beberapa faktor, diantaranya adalah kesuburan tanah, pengelolaan tanah, dan faktor iklim. Faktor-faktor tersebut akan berdampak pada pertumbuhan dan hasil produksi cabai, baik dari segi kuantitas maupun kualitas. Pengelolaan tanah yang seringkali dilakukan secara intensif dan tidak sesuai dengan syarat tumbuh dapat menyebabkan terjadinya penurunan kualitas tanah. Penurunan kualitas tanah tentu akan berpengaruh terhadap pertumbuhan dan produksi tanaman cabai merah besar. Salah satu upaya dalam memperbaiki penurunan kualitas tanah adalah dengan penambahan unsur hara, yang dapat dilakukan melalui kegiatan pemupukan dan pemberian zat pengatur tumbuh. Pemupukan dapat dilakukan dengan beberapa cara, diantaranya dengan pemupukan melalui daun tanaman menggunakan pupuk daun. Cara ini dilakukan dengan menyemprotkan pupuk yang telah dilarutkan pada daun dan jaringan tanaman. Pupuk daun yang diaplikasikan pada tanaman diketahui dapat lebih cepat memberikan nutrisi pada jaringan tanaman dibandingkan dengan pupuk yang diaplikasikan pada tanah. Penelitian yang dilakukan oleh Baloch, et al., (2008) menunjukkan bahwa aplikasi pupuk daun pada tanaman cabai dapat meningkatkan tinggi tanaman, jumlah cabang, jumlah buah per tanaman, panjang buah, berat buah segar, dan hasil buah segar.

Iklim juga menjadi faktor yang menyebabkan terjadinya penurunan hasil produksi tanaman cabai merah besar. Penanaman cabai pada musim hujan dapat berdampak pada hasil produksi tanaman cabai merah lebih sedikit daripada hasil produksi pada musim kemarau. Musim hujan cenderung menyebabkan kerontokan pada bunga dan buah sebelum waktu panen. Pemberian zat pengatur tumbuh merupakan salah satu upaya untuk mengurangi terjadinya penurunan hasil produksi pada musim hujan. Naphtalane Acetic Acid (NAA) merupakansalah satu zat pengatur tumbuh yang memiliki kemampuan untuk mempercepat proses pertumbuhan vegetatif dan generatif tanaman. Zat pengatur tumbuh NAA dapat berpengaruh terhadap pertumbuhan dan hasil produksi tanaman cabai merah besar seperti tinggi tanaman, jumlah bunga, jumlah buah, diameter buah, jumlah biji, umur panen terkahir dan frekuensi panen (Satriowibowo et al., 2014).

Berdasarkan uraian di atas, maka dilakukan penelitian untuk mengetahui pengaruh penambahan berbagai dosis zat pengatur tumbuh NAA pada pupuk daun terhadap sifat kimia tanah, kadar N, P, K dalam daun, pertumbuhan, dan produksi tanaman cabai merah besar.

\section{Bahan dan Metode \\ Waktu dan lokasi penelitian}

Penelitian dilaksanakan pada bulan November 2017 hingga Maret 2018 yang bertempat di Agro Techno Park, Desa Jatikerto, Kecamatan Kromengan, Kabupaten Malang. Analisis kimia tanah dan tanaman dilaksanakan di Laboratorium Kimia Jurusan Tanah, Fakultas Pertanian, Universitas Brawijaya, Malang.

\section{Rancangan penelitian}

Percobaan menggunakan Rancangan Acak Kelompok Faktorial (RAKF), terdiri atas 2 faktor yaitu dosis NAA dalam pupuk daun $(0 \%, 75 \%, 100 \%$, dan 125\%) dan interval aplikasi (14 dan 28 hari). Secara keseluruhan terdapat 8 kombinasi perlakuan, meliputi I1P1: Interval Aplikasi 14 Hari dan dosis NAA 0\%; I2P1: Interval Aplikasi 28 Hari dan dosis NAA 0\%; I1P2: Interval Aplikasi 14 Hari dan dosis NAA 75\%; I2P2: Interval Aplikasi 28 Hari dan dosis NAA 75\%; I1P3: Interval Aplikasi 14 Hari dan dosis NAA 100\%; I2P3: Interval Aplikasi 28 Hari dan dosis NAA 100\%; I1P4: Interval Aplikasi 14 Hari dan dosis NAA 125\%; dan I2P4: Interval Aplikasi 28 Hari dan dosis NAA 125\%; masing-masing perlakyan diulang sebanyak 3 kali.

\section{Pelaksanaan penelitian}

Kegiatan penelitian terdiri dari beberapa tahapan. Kegiatan pertama yaitu pengambilan sampel tanah yang dilakukan sebanyak dua kali, yaitu saat awal sebelum penanaman, dan saat 


\section{Jurnal Tanah dan Sumberdaya Lahan Vol 6 No 2 : 1301-1311, 2019 \\ e-ISSN:2549-9793, doi: 10.21776/ub.jts1.2019.006.2.11}

akhir setelah selesai panen terakhir. Contoh tanah komposit diambil pada kedalaman 0-20 $\mathrm{cm}$, dan digunakan untuk analisis kimia tanah meliputi pH, N-total, P-tersedia, K-tersedia, dan C-organik. Sebelum penanaman, dilakukan pengolahan lahan dan pembuatan petak penelitian (total sebanyak 24 petak penelitian). Petak penelitian berupa bedengan dibuat dengan ukuran $6 \mathrm{~m} \times 1 \mathrm{~m}$ dan jarak antar bedeng $60 \mathrm{~cm}$. Selanjutnya setiap bedeng diberi pupuk kandang dan pemasangan Mulsa Plastik Hitam Perak (MPHP). Kegiatan penanaman dilakukan dengan memindahkan bibit ke lubang tanam dengan jumlah satu tanaman per lubang tanam. Jarak tanam yang digunakan adalah $60 \mathrm{~cm} \times 60 \mathrm{~cm}$, dengan jumlah lubang tanam sebanyak 22 pada setiap bedengnya.

Aplikasi pupuk dasar Urea, Sp-36, dan $\mathrm{KCl}$ dilakukan pada 7 dan 28 Hari Setelah Tanam (HST). Untuk penambahan NAA di dalam pupuk daun, besarnya NAA (sesuai dosis) dilarutkan terlebih dahulu ke dalam pupuk daun. Untuk aplikasi di tanaman cabai merah besar, pupuk daun yang sudah bercampur dengan NAA (sesuai dosis perlakuan) diambil sebanyak $280 \mathrm{ml}(\sim 400$ $\mathrm{L} / \mathrm{ha}$ ) yang dilarukan ke dalam air $1 \mathrm{~L}$, kemudian disemprotkan ke tanaman cabai. Aplikasi pupuk daun yang dijadikan perlakuan dilakukan sesuai dengan interval waktu yang telah ditentukan (14 hari dan 28 hari). Untuk menghindari pengaruh perlakuan satu ke yang lain, pada saat aplikasi pupuk setiap bedeng dikelilingi oleh plastik. Aplikasi pupuk daun dilakukan pada pagi hari (antara pukul 06.0007.30 WIB) guna menghindari kehilangan pupuk akibat penguapan. Kegiatan pemeliharaan meliputi penyulaman, penyiangan gulma, pewiwilan, pemasangan ajir, dan pengendalian hama penyakit. Pemanenan dilakukan ketika buah cabai telah berwarna orange sampai merah.

Parameter pengamatan pada tanaman meliputi tinggi tanaman, jumlah daun, jumlah bunga, jumlah buah terbentuk, jumlah buah panen, dan bobot segar buah per tanaman, yang dilakukan setiap 2 minggu. Selanjutnya parameter sifat kesuburan tanah meliputi $\mathrm{pH}$, C-Organik, N-total, P-tersedia, dan K-tersedia), dan dilakukan juga pengukuran kadar $\mathrm{N}, \mathrm{P}$, dan $\mathrm{K}$ dalam daun tanaman cabai. Analisis data menggunakan analisis ragam (ANOVA) taraf $5 \%$. Apabila hasil analisis diperoleh perbedaan yang nyata $(\mathrm{P}<0.05)$, maka dilakukan uji lanjut menggunakan Duncan Multiple Range Test (DMRT) taraf 5\%.

\section{Hasil dan Pembahasan}

\section{Tinggi tanaman}

Hasil pengamatan tinggi tanaman menunjukkan bahwa perbedaan interval aplikasi pupuk daun dengan berbagai dosis NAA berpengaruh terhadap tinggi tanaman $(\mathrm{P}<0.05)$ pada 2,8 , 10, 12, 14, 16, dan 30 MST (minggu setelah tanam), dimana aplikasi pupuk daun yang diperkaya dengan NAA setiap 28 hari memiliki tinggi tanaman yang besar tinggi dibandingkan dengan interval aplikasi 14 hari. Hasil penelitian ini menunjukkan bahwa semakin intensif pemberian hormon pertumbuhan (NAA) tidak diikuti dengan peningkatan tinggi tanaman yang lebih besar dibandingkan apabila hormone pertumbuhan diberikan kurang intensif (setiap 28 hari). Secara keseluruhan, perbedaan dosis NAA dalam pupuk daun tidak berpengaruh pada tinggi tanaman kecuali pada minggu ke-2 setelah tanam. Penelitian ini juga tidak menemukan adanya interaksi antara berbagai dosis NAA dalam pupuk daun dengan interval aplikasi di dalam mempengaruhi tinggi tanaman cabai merah besar. Hasil pengamatan tinggi tanaman akibat perlakuan interval aplikasi dan dosis NAA terhadap tinggi tanaman cabai merah disajikan pada Gambar $1 \mathrm{a}$.

\section{Jumlah daun}

Sejalan dengan tinggi tanaman, perbedaan interval aplikasi pupuk daun yang diperkaya dengan hormone NAA mampu meningkatkan jumlah daun yang terbentuk pada 10, 12, dan 14 MST $(\mathrm{P}<0.05)$. Hasil rata-rata pengamatan jumlah daun berkisar antara $200-300$ helai per tanaman. Hal tersebut menunjukkan bahwa aplikasi pupuk daun tidak secara keseluruhan diserap secara optimal oleh tanaman. Kondisi cuaca saat aplikasi (turun hujan sebelum pupuk yang diberikan diserap oleh tanaman) ataupun keadaan lingkungan dapat berpengaruh terhadap respon tanaman akibat aplikasi pupuk daun. Selain itu, penyemprotan yang dilakukan 
hanya pada permukaan daun dapat mengakibatkan kurangnya penyerapan pupuk oleh daun. Novrizan, (2005) menyatakan bahwa pupuk diserap dan dapat masuk pada daun tanaman melalui stomata, sedangkan stomata berada pada daun bagian bawah. Jumlah daun akibat perlakuan interval aplikasi dan dosis NAA terhadap tanaman cabai merah disajikan pada Gambar 1b.
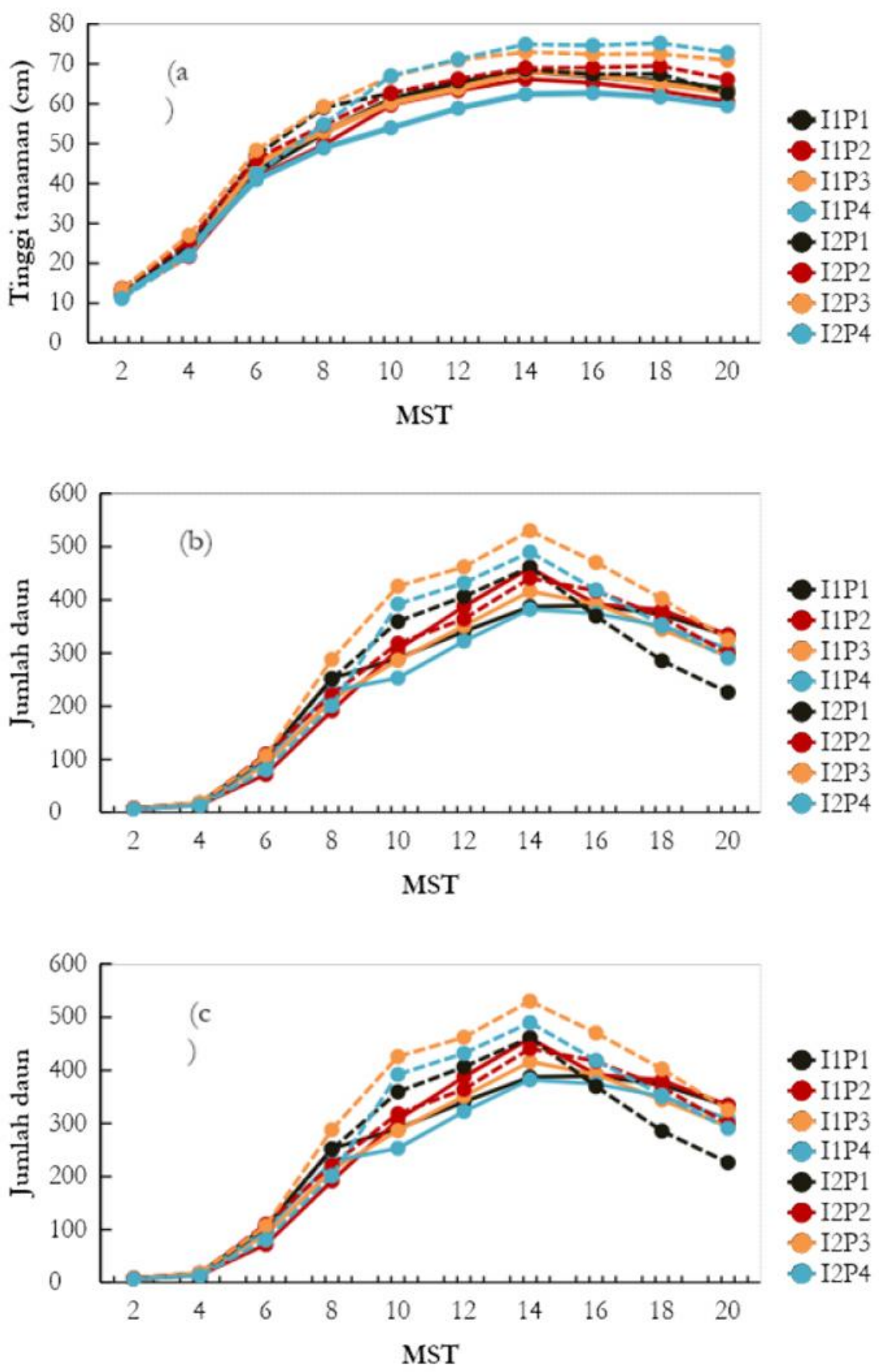

Gambar 1. Pengaruh interval aplikasi dan dosis NAA terhadap (a) tinggi tanaman; (b) jumlah daun; (c) kumulatif jumlah bunga cabai merah besar.

Keterangan: MST: Minggu Setelah Tanam; I1: Interval aplikasi 14 hari, I2: Interval aplikasi 28 hari, P1: 0\% NAA; P2: 75\% NAA; P3: 100\% NAA; P4: 125\% NAA 


\section{Jurnal Tanah dan Sumberdaya Lahan Vol 6 No 2 : 1301-1311, 2019 \\ e-ISSN:2549-9793, doi: 10.21776/ub.jts1.2019.006.2.11}

\section{Kumulatif jumlah bunga}

Berdasarkan hasil analisis ragam menunjukkan bahwa interaksi antara perlakuan interval aplikasi dan dosis NAA tidak memberikan pengaruh nyata terhadap kumulatif jumlah bunga pada seluruh pengamatan. Perlakuan interval aplikasi dan dosis NAA diketahui mampu berpengaruh terhadap kumulatif jumlah bunga pada setiap perlakuan meskipun tidak memberikan pengaruh nyata. Kumulatif jumlah bunga pada setiap perlakuan secara keseluruhan mengalami peningkatan tertinggi pada perlakuan I1P3 (Interval 14 hari, Pupuk daun $100 \%$ NAA) dengan rata-rata kumulatif sebesar 46 bunga per tanaman, diikuti perlakuan I2P1 (Interval aplikasi 28 hari, Pupuk daun $0 \%$ NAA) dengan rata-rata kumulatif sebesar 43 bunga per tanaman. Perlakuan I1P1 (Interval 14 hari, Pupuk daun $0 \%$ NAA) menjadi perlakuan yang mengalami peningkatan kumulatif bunga terendah dengan rata-rata kumulatif sebesar 35 bunga per tanaman. Supriyanti (2013), menyatakan bahwa faktor lingkungan seperti musim hujan dapat mempengaruhi pembentukan bunga. Musim hujan cenderung mengakibatkan kerontokan pada bunga, sehingga bunga yang muncul tidak dapat bertahan hingga memproduksi buah. Hasil pengamatan jumlah bunga akibat perlakuan interval aplikasi dan dosis NAA terhadap tanaman cabai merah disajikan pada Gambar 1c.

\section{Jumlah buah terbentuk}

Berdasarkan hasil analisis ragam menunjukkan bahwa interaksi antara perlakuan interval aplikasi dan dosis NAA hanya memberikan pengaruh nyata terhadap jumlah buah terbentuk pada pengamatan 12 dan 20 MST (Tabel 1). Perlakuan interval aplikasi dan dosis NAA diketahui berpengaruh terhadap jumlah buah terbentuk setiap perlakuan. Jumlah buah terbentuk mengalami peningkatan sampai dengan pengamatan 10 MST, dan mulai mengalami penurunan pada pengamatan 12 MST. Hasil rata-rata jumlah buah terbentuk menunjukkan bahwa perlakuan I2P3 (Interval aplikasi 28 hari, dosis 100\% NAA) memiliki pengaruh paling tinggi dengan rara-rata 25 buah/tanaman, sedangkan perlakuan I1P4 (Interval aplikasi 14 hari, dosis 125\% NAA) memiliki pengaruh paling rendah terhadap jumlah buah terbentuk dengan rara-rata 16 buah/tananaman. Jumlah buah terbentuk dapat dipengaruhi oleh jumlah bunga tanaman. Selain itu, faktor lingkungan seperti curah hujan dapat mempengaruhi pembuahan dan pembentukan buah. Hujan yang terjadi dapat menerpa tanaman sehingga menyebabkan buah yang terbentuk menjadi rusak dan rontok (Hardjowigeno, 2015).

Tabel 1. Pengaruh interval aplikasi dan dosis NAA terhadap jumlah buah terbentuk.

\begin{tabular}{|c|c|c|c|c|c|c|c|c|}
\hline \multirow{2}{*}{$\begin{array}{l}\text { Perla- } \\
\text { kuan }\end{array}$} & \multicolumn{8}{|c|}{ Jumlah Buah Terbentuk (buah/tanaman) } \\
\hline & $6 \mathrm{MST}$ & 8 MST & 10 MST & 12 MST & 14 MST & 16 MST & 18 MST & $20 \mathrm{MST}$ \\
\hline I1P1 & 5,93 & 21,59 & 34,61 & $43,39 \mathrm{bc}$ & 15,56 & 14,01 & 18,06 & $13,28 \mathrm{ab}$ \\
\hline I1P2 & 3,71 & 13,86 & 30,00 & $39,33 \mathrm{abc}$ & 26,33 & 13,67 & 21,27 & $16,40 \mathrm{~b}$ \\
\hline I1P3 & 5,03 & 17,64 & 24,89 & $25,56 \mathrm{a}$ & 23,83 & 20,91 & 16,97 & $12,09 \mathrm{ab}$ \\
\hline I1P4 & 4,50 & 13,36 & 29,22 & $28,83 \mathrm{ab}$ & 17,20 & 16,22 & 11,49 & $9,56 \mathrm{ab}$ \\
\hline $\mathrm{I} 2 \mathrm{P} 1$ & 4,93 & 24,19 & 44,61 & $41,83 \mathrm{abc}$ & 12,94 & 9,10 & 14,57 & $17,36 \mathrm{~b}$ \\
\hline $\mathrm{I} 2 \mathrm{P} 2$ & 4,64 & 15,51 & 31,17 & $30,22 \mathrm{ab}$ & 17,11 & 13,71 & 10,46 & 7,36 a \\
\hline $\mathrm{I} 2 \mathrm{P} 3$ & 5,06 & 25,00 & 51,68 & $50,03 \mathrm{c}$ & 16,50 & 15,62 & 19,92 & $14,81 \mathrm{ab}$ \\
\hline $\mathrm{I} 2 \mathrm{P} 4$ & 2,27 & 18,17 & 44,81 & $39,94 \mathrm{abc}$ & 14,08 & 15,69 & 16,57 & $14,96 \mathrm{ab}$ \\
\hline $\begin{array}{c}\text { DMRT } \\
5 \% \\
\end{array}$ & tn & tn & th & $*$ & th & tn & tn & $*$ \\
\hline
\end{tabular}

Keterangan: tn: tidak berbeda nyata; $*=$ berbeda nyata (5\%); Angka-angka yang diikuti huruf yang berbeda pada kolom yang sama menunjukkan ada perbedaan nyata pada uji DMRT 5\%; MST: Minggu Setelah Tanam; I1: Interval aplikasi 14 hari, I2: Interval aplikasi 28 hari, P1: 0\% NAA; P2: 75\% NAA; P3: 100\% NAA; P4: $125 \%$ NAA. 


\section{Produksi tanaman}

Pada interval aplikasi 14 hari (Gambar 2a.), bobot segar buah per tanaman tertinggi diperoleh pada perlakuan P2 (dosis 75\% NAA) dengan rata-rata sebesar $341.2 \mathrm{~g} /$ tanaman, diikuti oleh P3 (dosis 100\% NAA; 301 $\mathrm{g} /$ tanaman), perlakuan P4 (dosis 125\% NAA; $278.2 \mathrm{~g} /$ tanaman), dan terendah pada perlakuan P1 (dosis $0 \%$ NAA; 269.1

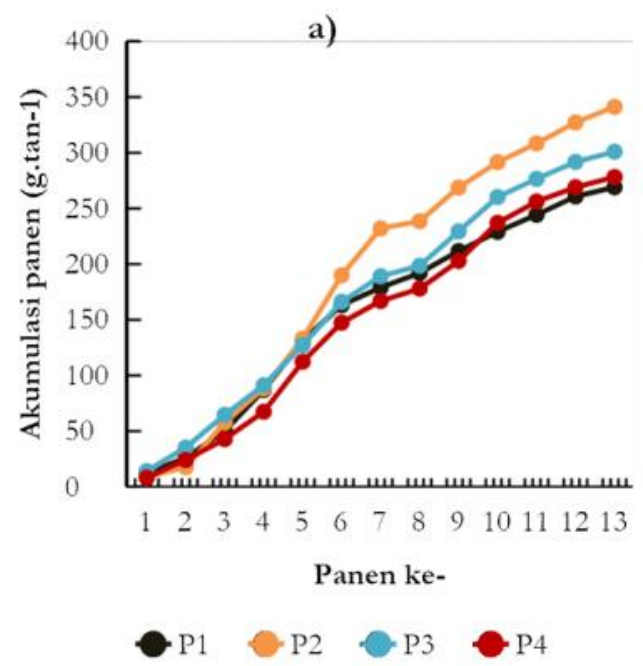

$\mathrm{g} /$ tanaman). Sedangka pada interval aplikasi 28 hari (Gambar 2b), perlakuan P3 (dosis 100\% NAA) menghasilkan bobot segar per tanaman tertinggi (rata-rata sebesar $326.4 \mathrm{~g} /$ tanaman), diikuti perlakuan P4 (dosis 125\% NAA; 326.2 $\mathrm{g} /$ tanaman), perlakuan P1 (dosis 0\% NAA; $318.7 \mathrm{~g} /$ tanaman), dan terendah pada perlakuan P2 (dosis 75\% NAA; 290.1 $\mathrm{g} /$ tanaman).

Gambar 2. Rerata kumulatif bobot segar buah per tanaman cabai (a: interval 14 hari; b: interval 28 hari).

Keterangan:P1: 0\% NAA; P2: 75\% NAA; P3: 100\% NAA; P4: 125\% NAA. P1: Pupuk daun 0\% NAA; P2: Pupuk daun 75\% NAA; P3: Pupuk daun 100\% NAA; P4: Pupuk daun 125\% NAA.

\section{Kesuburan tanah}

pH tanah

Kemasaman tanah merupakan salah satu indikator kesuburan tanah. Hasil analisis tanah awal sebelum dilakukan penanaman menunjukkan bahwa $\mathrm{pH}$ tanah di lokasi penelitian tergolong masam dengan nilai sebesar 4.91. Bedasarkan hasil analisis ragam, interaksi antara interval aplikasi dan dosis NAA tidak memberikan pengaruh nyata terhadap $\mathrm{pH}$ tanah. Meskipun demikian, aplikasi pupuk daun dengan interval berbeda diketahui dapat meningkatkan nilai $\mathrm{pH}$ tanah dibandingkan dengan analisis awal. Nilai $\mathrm{pH}$ tanah pada setiap perlakuan mengalami peningkatan menjadi berkisar 5.49 - 5.82 dan termasuk dalam kriteria $\mathrm{pH}$ agak masam. Rendahnya nilai $\mathrm{pH}$ pada analisis akhir dapat disebabkan karena penambahan bahan organik (melalui pupuk kandang) dalam tanah. Pupuk yang diaplikasikan melalui daun akan lebih banyak diserap secara langsung oleh daun, sehingga unsur hara yang berada di tanah lebih rendah. Hal ini sesuai dengan pernyataan Atmojo (2001), bahwa peningkatan $\mathrm{pH}$ tanah akan terjadi apabila bahan organik yang ditambahkan dalam tanah telah terdekomposisi langsung (matang), karena bahan organik yang telah mengalami mineralisasi akan melepaskan mineralnya berupa kation-kation basa

\section{C-Organik tanah}

Hasil analisis C-organik tanah awal (1.19\%) menunjukkan bahwa nilai kandungan Corganik dalam tanah tergolong kriteria sedang. Bedasarkan hasil analisis ragam, interaksi antara interval aplikasi dan dosis NAA tidak 


\section{Jurnal Tanah dan Sumberdaya Lahan Vol 6 No 2 : 1301-1311, 2019 e-ISSN:2549-9793, doi: 10.21776/ub.jts1.2019.006.2.11}

memberikan pengaruh nyata terhadap Corganik tanah. Hasil analisis akhir tanah menunjukkan terdapat perlakuan yang mengalami peningkatan C-organik tanah namun masih dalam kriteria yang sama, dengan peningkatan tertinggi terdapat pada perlakuan I1P3 (Interval aplikasi 14 hari, dosis 100\% NAA). Hasil analisis akhir tanah juga menunjukkan bahwa terjadi penurunan nilai Corganik tanah yang diikuti penurunan kriteria menjadi rendah dibandingkan dengan analisis awal. Nilai C-organik paling rendah terdapat pada perlakuan I2P1 (Interval aplikasi 28 hari, dosis $0 \%$ NAA). Tidak adanya peningkatan yang signifikan pada C-organik tanah dapat dikarenakan penambahan bahan organik pada tanah melalui pupuk kandang masih kurang. $\mathrm{pH}$ tanah juga dapat mempengaruhi nilai Corganik dalam tanah terutama mempengaruhi kegiatan organisme dalam mendekomposisi bahan organik menjadi lebih cepat, sehingga akan mempengaruhi nilai C-organik tanah (Hardjowigeno, 2015).

\section{N-total tanah}

Hasil analisis tanah pada saat panen menunjukkan adanya peningkatan N-total tanah pada seluruh perlakuan dibandingkan dengan analisis awal $\mathrm{N}$-total tanah $(\mathrm{N}$ total tanah $0.07 \%$ dan tergolong kriteria sangat rendah). Bedasarkan hasil analisis ragam, tidak ada pengaruh nyata antara perlakuan interval aplikasi dan dosis NAA terhadap N-total tanah. Nilai akhir analisis N-total tanah mengalami peningkatan berkisar $0.11-0.12 \%$ dan termasuk dalam kriteria rendah. Aplikasi pupuk daun dengan interval berbeda diketahui dapat meningkatkan N-total tanah. Meskipun telah terjadi peningkatan N-Total tanah sebesar 57\%, namun $\mathrm{N}$ dalam tanah masih tergolong rendah. Rendahnya N-total dapat disebabkan karena sifat $\mathrm{N}$ yang mudah menguap ke udara dan tercuci oleh air hujan (Hardjowigeno, 2015). Selain itu, kegiatan pelepasan nitrogen menjadi $\mathrm{N}$ total tanah dapat dipengaruhi oleh $\mathrm{pH}$ tanah. Peningkatan $\mathrm{pH}$ tanah akan meningkatkan pelepasan $\mathrm{N}$ dan berpengaruh terhadap penurunan $\mathrm{N}$ total tanah (Hanafiah, 2005).

\section{P-tersedia tanah}

Hasil analisis tanah awal sebelum dilakukan sebelum perlakuan menunjukkan bahwa P- tersedia tanah tergolong rendah dengan nilai sebesar $9.01 \mathrm{mg} / \mathrm{kg}$. Bedasarkan hasil analisis ragam, interaksi antara interval aplikasi dan dosis NAA tidak memberikan pengaruh nyata terhadap P-tersedia tanah. Meskipun demikian, aplikasi pupuk daun dengan interval berbeda diketahui dapat meningkatkan P-tersedia tanah dibandingkan dengan analisis awal pada seluruh perlakuan. Nilai P-tersedia tanah pada setiap perlakuan mengalami peningkatan berkisar 54.69 - $99.57 \mathrm{mg} / \mathrm{kg}$ dan termasuk kriteria sangat tinggi. Penambahan bahan organic (pupuk kandang) dapat membantu meningkatkan P-tersedia dalam tanah. Penelitian yang telah dilakukan oleh Sari et. al. (2017), menunjukkan bahwa penambahan berbagai bahan organik mampu meningkatkan $\mathrm{pH}$ tanah, yang diikuti dengan peningkatan Ptersedia dalam tanah.

\section{$K$-dapat dipertukarkan $(K-d d)$}

Hasil analisis awal tanah menunjukkan bahwa K-dd tergolong kriteria sangat tinggi dengan nilai sebesar $2.16 \mathrm{me} / 100 \mathrm{~g}$. Bedasarkan hasil analisis ragam, interaksi antara interval aplikasi dan dosis NAA tidak memberikan pengaruh nyata terhadap K-dd tanah. Aplikasi pupuk daun dengan interval berbeda diketahui mengalami penurunan pada setiap perlakuan dari 2.6 me $/ 100 \mathrm{~g}$ menjadi 1.14 - $1.56 \mathrm{me} / 100 \mathrm{~g}$ dengan kriteria tetap, yaitu sangat tinggi. Penurunan nilai K-dd dalam tanah dapat dipengaruhi oleh curah hujan yang tinggi pada saat budidaya. Sutedjo (2002), menyatakan bahwa kation $\mathrm{K}^{+}$dalam tanah dapat hilang akibat ikut tercuci bersama air hujan yang meresap ke dalam tanah. Adanya penurunan hara kalium dalam tanah setelah penelitian dapat disebabkan beberapa faktor. Kalium dalam tanah dapat berkurang karena adanya proses pencucian (leaching). Selain itu, kalium dapat berkurang karena telah diserap dan dimanfaatkan oleh tanaman. Unsur $K$ pada tanaman memiliki peranan penting setelah unsur $\mathrm{N}$ dan P. Kalium berperan dalam membantu meningkatkan kualitas buah dan biji pada tanaman (Hanafiah, 2005). Kehilangan kalium akibat terangkut tanaman dapat lebih besar terjadi akibat sifat kalium yang dapat diserap secara berlebihan. Meskipun demikian, kalium yang diserap berlebih tidak akan 


\section{Jurnal Tanah dan Sumberdaya Lahan Vol 6 No 2 : 1301-1311, 2019 \\ e-ISSN:2549-9793, doi: 10.21776/ub.jts1.2019.006.2.11}

meningkatkan hasil tanaman, karena kalium yang tersedia telah melebihi kebutuhan tanaman. Akibatnya, ketersediaan kalium dalam tanah menjadi berkurang (Budi dan Sari, 2015).

Tabel 2. Pengaruh interval aplikasi dan dosis NAA terhadap sifat kimia tanah.

\begin{tabular}{cccccc}
\hline Perlakuan & pH & $\begin{array}{c}\text { N-total } \\
(\mathbf{\%})\end{array}$ & $\begin{array}{c}\text { P-tersedia } \\
(\mathbf{m g} / \mathbf{k g})\end{array}$ & K-dd (me/100g) & $\begin{array}{c}\text { C-organik } \\
(\mathbf{\%})\end{array}$ \\
\hline Awal & $4,91 \mathrm{~m}$ & $0,07 \mathrm{sr}$ & $9,01 \mathrm{r}$ & $2,16 \mathrm{st}$ & $1,19 \mathrm{~s}$ \\
\hline I1P1 & $5.62 \mathrm{am}$ & $0.11 \mathrm{r}$ & $64.05 \mathrm{st}$ & $1.27 \mathrm{st}$ & $0.94 \mathrm{r}$ \\
I1P2 & $5.49 \mathrm{am}$ & $0.11 \mathrm{r}$ & $71.48 \mathrm{st}$ & $1.49 \mathrm{st}$ & $0.96 \mathrm{r}$ \\
I1P3 & $5.82 \mathrm{am}$ & $0.11 \mathrm{r}$ & $99.57 \mathrm{st}$ & $1.21 \mathrm{st}$ & $1.48 \mathrm{~s}$ \\
I1P4 & $5.60 \mathrm{am}$ & $0.11 \mathrm{r}$ & $55.02 \mathrm{st}$ & $1.14 \mathrm{st}$ & $1.26 \mathrm{~s}$ \\
I2P1 & $5.61 \mathrm{am}$ & $0.12 \mathrm{r}$ & $59.47 \mathrm{st}$ & $1.56 \mathrm{st}$ & $0.92 \mathrm{r}$ \\
I2P2 & $5.64 \mathrm{am}$ & $0.11 \mathrm{r}$ & $54.69 \mathrm{st}$ & $1.46 \mathrm{st}$ & $1.39 \mathrm{~s}$ \\
I2P3 & $5.69 \mathrm{am}$ & $0.12 \mathrm{r}$ & $83.52 \mathrm{st}$ & $1.20 \mathrm{st}$ & $0.99 \mathrm{r}$ \\
I2P4 & $5.70 \mathrm{am}$ & $0.11 \mathrm{r}$ & $55.43 \mathrm{st}$ & $1.37 \mathrm{st}$ & $1.21 \mathrm{~s}$ \\
\hline DMRT 5\% & $\mathrm{tn}$ & $\mathrm{tn}$ & $\mathrm{tn}$ & $\mathrm{tn}$ & $\mathrm{tn}$ \\
\hline
\end{tabular}

Keterangan sama dengan Tabel 1.

\section{Kadar N, P, dan K dalam daun pada 63 HST}

Hasil analisis ragam menunjukkan bahwa interaksi interval aplikasi dan dosis NAA tidak berpengaruh nyata terhadap kadar $\mathrm{N}$ dalam daun tanaman cabai besar. Pengamatan kadar $\mathrm{N}$ menunjukkan nilai tertinggi sebesar 8.07\% pada perlakuan I1P4 (Interval aplikasi 14 hari, Pupuk daun 125\% NAA), diikuti oleh I2P1 (Interval aplikasi 14 hari, dosis 0\% NAA) sebesar 8.05\%. Perlakuan I2P4 (Interval aplikasi 28 hari, dosis 125\% NAA) memiliki kadar $\mathrm{N}$ daun paling rendah dengan nilai 6.95\%. Lebih lanjut, interaksi interval aplikasi dan dosis NAA juga tidak berpengaruh nyata terhadap kadar P dalam daun cabai besar. Pengamatan kadar P dalam daun cabai besar menunjukkan nilai tertinggi sebesar $0.53 \%$ pada perlakuan I1P1 (Interval aplikasi 14 hari, dosis $0 \%$ NAA), sedangkan nilai terendah terdapat pada perlakuan I2P3 (Interval aplikasi 28 hari, dosis $100 \%$ NAA) dengan nilai $0.44 \%$. Hasil penelitin juga tidak menemukan adanya interaksi yang nyata antara interval aplikasi dan dosis NAA di dalam mempengaruhi kadar K dalam daun cabai besar. Pengamatan kadar K dalam daun cabai besar menunjukkan nilai sebesar $8.15 \%$ pada perlakuan I2P4 (Interval aplikasi 28 hari, dosis 125\% NAA), diikuti perlakuan I1P4 (Interval aplikasi 14 hari, dosis 125\% NAA) dengan kadar K sebesar 7.98\%. Perlakuan I1P3 (Interval aplikasi 14 hari, dosis 100\% NAA) memiliki kadar $\mathrm{K}$ terendah dengan nilai $7.08 \%$.

Tabel 3. Pengaruh interval aplikasi dan dosis NAA terhadap kadar N, P, K dalam daun.

\begin{tabular}{cccc}
\hline \multirow{2}{*}{ Perlakuan } & \multicolumn{3}{c}{ Kadar Hara dalam Daun (\%) } \\
\cline { 2 - 4 } & $\mathbf{N}$ & $\mathbf{P}$ & $\mathbf{K}$ \\
I1P1 & 7,02 & 0,53 & 7,81 \\
I1P2 & 7,12 & 0,46 & 7,36 \\
I1P3 & 7,19 & 0,47 & 7,08 \\
I1P4 & 8,07 & 0,49 & 7,98 \\
I2P1 & 8,05 & 0,46 & 7,37 \\
I2P2 & 7,05 & 0,48 & 7,67 \\
I2P3 & 7,18 & 0,44 & 7,16 \\
I2P4 & 6,95 & 0,49 & 8,15 \\
\hline DMRT 5\% & tn & tn & tn \\
\hline
\end{tabular}

Keterangan sama dengan Tabel 1. 


\section{Hubungan antara sifat kimia tanah dengan pertumbuhan dan produksi tanaman cabai merah besar}

Pengamatan pertumbuhan dan hasil tanaman cabai menunjukkan bahwa perlakuan P3 (dosis $100 \%$ NAA) dan P4 (dosis 125\% NAA) dengan interval aplikasi 28 hari (I2) lebih mampu mempengaruhi pertumbuhan tanaman dibandingkan dengan perlakuan lainnya. Aplikasi pupuk daun dengan interval berbeda diketahui dapat memberikan pengaruh berbeda pada tanaman. Interval aplikasi 28 hari lebih mampu memberikan hasil terbaik dibandingkan interval aplikasi 14 hari. Peningkatan pada pengamatan pertumbuhan dan hasil tanaman akibat perlakuan dapat memperlihatkan dosis NAA efektif dan waktu aplikasi yang tepat bagi tanaman. Singh (2015) menyatakan bahwa dosis aplikasi NAA yang efektif dapat membantu pemanfaatan makanan pada tanaman lebih efisien, dapat mengurangi transpirasi dan respirasi, sehingga tanaman dapat lebih optimal dalam proses pertumbuhan dan produksi (bunga dan buah). Berdasarkan uji korelasi P-tersedia terhadap kumulatif jumlah bunga (Gambar 3) menunjukkan adanya hubungan positif antar dua faktor. Apabila terjadi peningkatan P-tersedia di tanah maka jumlah bunga juga akan meningkat. Unsur P diketahui berguna untuk merangsang pertumbuhan akar pada tanaman, mempercepat pembungaan, pemasakan biji dan buah (Lingga dan Marsono, 2008). Hal tersebut diperkuat dengan penelitian Subuwo dan Sudjadi (1990), yang menyatakan bahwa unsur P dapat mempengaruhi pertumbuhan tanaman, diantaranya mampu merangsang pembungaan, pembuahan, dan pertumbuhan biji. Beberapa faktor dapat mempengaruhi keberhasilan aplikasi pupuk daun, salah satunya faktor lingkungan. Budidaya yang dilakukan saat musim hujan dapat berpengaruh terhadap kondisi tanah dan tanaman. Supriyanti (2013), menyatakan bahwa musim hujan cenderung mengakibatkan kerontokan pada bunga, sehingga bunga yang muncul tidak dapat memproduksi buah. Curah hujan yang tinggi saat budidaya juga dapat memungkinkan adanya pencucian hara pada daun sebelum dapat diserap sempurna oleh tanaman. Berdasarkan data pengamatan curah hujan di tempat budidaya, rata-rata curah hujan harian pada bulan Januari-Maret berkisar 22-33 mm dan termasuk dalam kriteria hujan sedang. Hal tersebut sesuai dengan penelitian Hastuti (2009), yang menyatakan bahwa curah hujan yang tinggi dapat memungkinkan pupuk tercuci oleh air hujan sebelum diserap sempurna oleh tanaman, sehingga tidak memberikan pengaruh terhadap pertumbuhan tanaman.

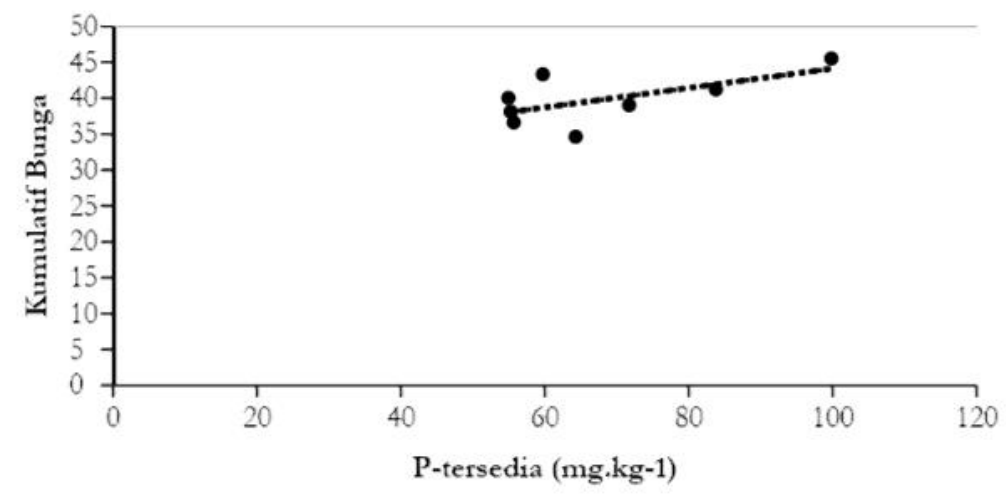

Gambar 3. Hubungan P-tersedia terhadap kumulatif jumlah bunga.

\section{Hubungan antara sifat kimia tanah dengan kadar NPK daun tanaman cabai merah besar}

$\mathrm{pH}$ tanah diketahui memiliki hubungan erat dengan ketersediaan $\mathrm{P}$ dalam tanah (Gambar
4). Ifansyah (2013) menyatakan bahwa peningkatan nilai $\mathrm{pH}$ selalu diikuti oleh peningkatan P-tersedia. P-tersedia dapat dijumpai dalam tanah pada kisaran pH 5.5-7.0. Unsur P dalam tanah akan cederung terjerap oleh $\mathrm{Al}$ dan $\mathrm{Fe}$ apabila $\mathrm{pH}$ tanah di bawah 5.5 
(keadaan masam), sedangkan $\mathrm{P}$ dalam tanah cederung terjerat oleh $\mathrm{Ca}$ dan $\mathrm{Mg}$ apabila $\mathrm{pH}$ di atas 7.7 (keadaan basa). Hal ini menyebabkan $\mathrm{P}$ tidak dapat tersedia bagi tanaman (Budi dan Sari, 2015). Unsur hara yang diberikan pada tanaman akan berpengaruh terhadap pertumbuhan dan hasil tanaman itu sendiri.
Tanaman akan memanfaatkan unsur hara yang diberikan dengan cara proses fotosintesis. Hasil analisis kadar N, P, dan $\mathrm{K}$ dalam daun tanaman cabai tidak memberikan pengaruh nyata akibat interaksi interval aplikasi dan dosis NAA. Hal ini dapat terjadi karena unsur hara pada tanaman telah diserap oleh tanaman.

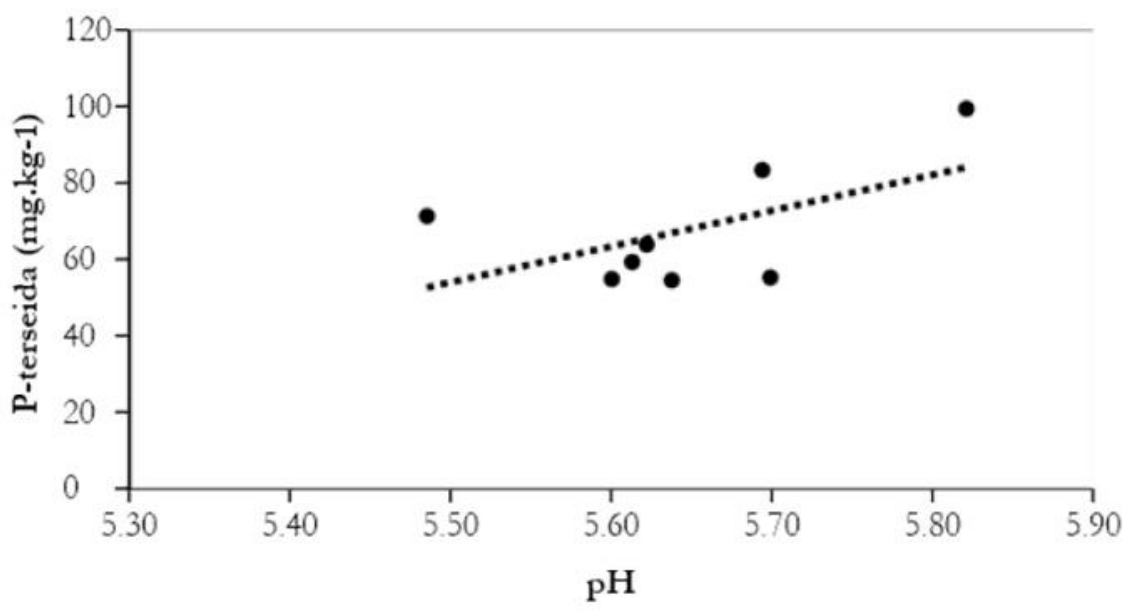

Gambar 4. Hubungan pH terhadap P-tersedia.

Pemupukan melalui daun diketahui cukup baik untuk menekan tingkat fiksasi unsur-unsur sehingga unsur-unsur yang diperlukan oleh tanaman akan lebih cepat tersedia (Lingga dan Marsono, 2008). Pupuk yang diaplikasikan pada daun akan lebih banyak diserap oleh tanaman secara langsung. Selanjutnya, unsur hara akan diproses membentuk senyawa-senyawa organik untuk membentuk bagian-bagian tanaman (Budi dan Sari, 2015).

\section{Kesimpulan}

Pupuk daun dengan penambahan NAA tidak memberikan pengaruh nyata terhadap pertumbuhan, produksi tanaman, sifat kimia tanah, dan kadar NPK dalam daun tanaman cabai merah. Hasil tertinggi pada tinggi tanaman, jumlah daun, kumulatif jumlah bunga, dan produksi tanaman akibat perlakuan secara berurutan adalah I2P4 (Interval aplikasi 28 hari, Dosis NAA 125\%), I2P3 (Interval aplikasi 28 hari, Dosis NAA 100\%), I1P3 (Interval aplikasi 14 hari, Dosis NAA 100\%), dan I1P2 (Interval aplikasi 14 hari, Dosis NAA
$75 \%$ ). Sedangkan hasil tertinggi pada $\mathrm{pH}, \mathrm{C}-$ Organik, N-total, P-tersedia, K-tersedia, akibat perlakuan secara berurutan adalah I1P3 (Interval aplikasi 14 hari, Dosis NAA 100\%), (Interval aplikasi 14 hari, Dosis NAA 100\%), I2P3 (Interval aplikasi 28 hari, Dosis NAA 100\%), I1P3 (Interval aplikasi 14 hari, Dosis NAA 100\%), I2P1 (Interval aplikasi 28 hari, Dosis NAA 0\%). Sedangkan hasil tertinggi pada kadar $\mathrm{N}$ dalam daun, kadar $\mathrm{P}$ dalam daun, dan kadar $\mathrm{K}$ dalam daun akibat perlakuan secara berurutan adalah I1P4 (Interval aplikasi 14 hari, Dosis NAA 125\%), I1P1 (Interval aplikasi 14 hari, Dosis NAA 0\%), dan I2P4 (Interval aplikasi 28 hari, Dosis NAA 125\%).

\section{Ucapan Terima Kasih}

Penelitian ini merupakan bagian dari kerjasama penelitian antara Jurusan Tanah, Fakultas Pertanian - Universitas Brawijaya dengan PT. Ajinomoto dalam upaya mempelajari efektivitas aplikasi hormon NAA pada pupuk daun untuk tanaman cabai merah besar. 


\section{Daftar Pustaka}

Atmojo, S.W. 2001. Pengaruh residu penggunaan bahan organik, dolomit, dan kcl pada tanaman kacang tanah (Arachis byphogea L.) pada oxic dystrudept di Jumapolo, Karanganyar. Jurnal Habitat 12 (3), 170-177.

Baloch, Q., Chachar, Q.I. and Tareen, M.N. 2008. Effect of foliar application of macro and micro nutrients on production of green chilies (Capsicum annuum L..). Journal of Agricultural Technology 4 (2), 177-184.

Budi, S., dan Sari, S 2015. Ilmu dan Implementasi Kesuburan Tanah. UMM Press, Malang.

Hanafiah, K.A. 2005. Dasar-Dasar Ilmu Tanah. Raja Grafindo Persada. Jakarta.

Hardjowigeno, S. 2015. Ilmu Tanah. Akademi Presindo, Jakarta.

Hastuti, F. 2009. Pengaruh Konsentrasi Pupuk Daun terhadap Pertumbuhan vegetative Tabulampot Buah Naga (Hylocereus undatus (Haw.) Britt. Et R). Skripsi. Institut Pertanian Bogor, Bogor.

Ifansyah, H. 2013. soil and $\mathrm{pH}$ solubility of allumunium, iron, and phosporous in ultisols: the roles of humic acid. Journal of Tropical Soils 18 (3), 203-208.

Lingga, P. dan Marsono. 2008. Petunjuk Penggunaan Pupuk. Seri Agrotek. Penebar Swadaya, Jakarta.

Novrizan. 2005. Petunjuk Pemupukan Efektif. Agromedia Pustaka, Jakarta.
Pusat Data dan Sistem Informasi Pertanian. 2016. Outlook Komoditas Pertanian Sub Sektor Hortikultura: Cabai Merah. Sekretariat Jenderal Kementrian Pertanian, Jakarta.

Sari, M.N., Sudarsono, dan Darmawan. 2017. Pengaruh bahan organik terhadap ketersediaan fosfor pada tanah-tanah kaya $\mathrm{Al}$ dan Fe. Buletin Tanah dan Lahan 1 (1), 65-71.

Satriowibowo, E.A., Nawawi, M. dan Koesriharti. 2014. Pengaruh waktu aplikasi dan konsentrasi NAA (Napthalene Acetic Acid) pada pertumbuhan dan hasil tanaman cabai besar (Capsicum annuum L..) varietas jet set. Jurnal Produksi Tanaman 2 (4), 282-291.

Singh, D.K., Rudra, B.C., Das, B. and. Gangopadhyay, P.K. 2015. Effect of naphtalene acetic acid on yield of chilli (Capsicum annum $\mathrm{L}$.). Journal of Agricultre Technology 2 (1-2), 84-86.

Subuwo, J.S., dan Sudjadi, M. 1990. Pengaruh Bahan Organik terhadap Pencucian Tanah Ultisol Rangkasbitung, Jawa Barat. Pemberitaan Penelitian Tanah dan Pupuk. Bogor, 1990, pp 26-31.

Supriyanti, A. 2013. Perakitan dan Seleksi Tanaman Cabai (Capsicum annum L.) Tahan CMV (Cucumber Mozaik Virus). Budidaya Pertanian, Universitas Gadjah Mada, Yogyakarta.

Sutedjo, M. 2002. Pupuk dan Cara Pemupukan. Rineka Cipta, Jakarta. 